\title{
Past, present, and future of gifted science education in Korea: a historical perspective
}

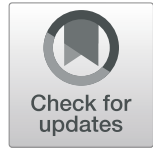

Da Yeon Kang®

\author{
Correspondence: dayeon.kang.9@ \\ gmail.com \\ Graduate School of Science \\ Education, College of Education, \\ Seoul National University, Building \\ 13, Rm 326, Gwanak-ro 1, \\ Gwanak-gu, Seoul, Republic of \\ Korea08826
}

\begin{abstract}
The Republic of Korea is well known as a leader of gifted science education due to the significant progress it has made in the past two decades. This paper aims to provide a historical perspective of gifted science education in Korea by interviewing a key figure in the Korean science education community. This paper explores the various trajectories of the development of gifted science education via the experience and thoughts of Choe Seung-Urn, who is a founder and developer of gifted science education in Korea. He has participated in gifted science education in Korea since the beginning by building prototypes of gifted education institutes, introducing tools to identify gifted students, and developing an orchestrated and integrated model across both research and education. This conversation with a senior researcher on the brink of retirement is intended to provide a deeper insight for successive generations who will take over the gifted science education system.

Keywords: Science education, Gifted education, Policy and implementation, Giftedness
\end{abstract}

\section{초록}

지난 20년 간 한국의 과학영재교육은 발전을 이루어 왔으며, 전 세계적으로 그 성과를 인정받고 있다. 이에 본 논문에서는 한국의 과학영재교육에 평생을 바쳐 온 한 교수와의 인터뷰를 통해 그 역사와 발전 과정을 되짚어 보고자 하 였다. 서울대학교 지구과학교육과의 최승언 교수는 동료 연구자들과 함께 영 재교육기관의 전신을 만들고 영재성 판별검사를 개발하는 등 영재교육의 토대 를 정립하고 발전시키는 데에 크게 기여해 온 인물이다. 본 논문에서는 한국 영재교육의 발전과정에 참여한 그의 경험과 생각을 통해, 한국의 과학영재교 육의 과거와 현재, 그리고 미래에 대해 논의하였다. 은퇴를 앞둔 노학자와의 대화는 앞으로 과학영재교육계를 이어받을 후속 세대에게 깊은 통찰을 줄 수 있을 것이다.

\section{About the paper}

The Republic of Korea (hereafter referred to as Korea) is currently considered a leader in gifted education due to its outstanding performance in research and students' achievement over the last 20 years. Gifted education in Korea was institutionally established by the Promotion of Education for the Gifted and Talented Law (영재교육진흥법), which came into force in 2000 (Korean Ministry of Education, 2003). In the years since then there have been enormous nationwide contributions in research related to gifted education; for instance, there were 1696 journal publications, 138 doctoral theses, and 1470

(C) The Author(s). 2019 Open Access This article is distributed under the terms of the Creative Commons Attribution 4.0 International License (http://creativecommons.org/licenses/by/4.0/), which permits unrestricted use, distribution, and reproduction in any medium, provided you give appropriate credit to the original author(s) and the source, provide a link to the Creative Commons license, and indicate if changes were made. 
master's dissertations published from 2003 to 2012 (Lee \& Choi, 2015). This trend is ongoing: A keyword search using "gifted students" ( “영재” ) returned 6869 journal publications in the Korean research database Research Information Sharing Service (RISS). In science specifically, 2763 journal publications were found in the same database. ${ }^{1}$ Aligned with intensive interest in research, Korean students are known for their outstanding achievements in science. International benchmarks such as the Programme for International Student Assessment (PISA) study or the Trends in International Mathematics and Science Study (TIMSS) have shown high rankings for Korean students in recent decades (Martin, Mullis, \& Foy, 2008; Martin, Mullis, Foy, \& Hooper, 2016; Organization for Economic Cooperation and Development [OECD], 2014, 2016). Also, Korean students have recorded outstanding performance in international Olympiads in mathematics and science every year (Bak, 2017; Korean Ministry of Science and ICT, 2017; Lee, 2015; Marica, 2014; Yi, 2017). As of 2019, 109,266 students are receiving gifted education at 2479 institutions nationwide, with most (77.3\%) of the gifted education being conducted in mathematics and science (Gifted Education Database, 2019).

In view of this, Sonya N. Martin, editor-in-chief of the Asia-Pacific Science Education journal, requested that Choe Seung-Urn ${ }^{2}$ be interviewed in celebration of gifted science education in Korea. Since the early 2000s when gifted education began, he has been a leading figure in gifted science education in Korea. In this interview, Professor Choe Seung-urn examines the development process of gifted science education in Korea from his point of view of his research at the forefront of gifted science education in Korea and examines the direction of gifted science education in Korea through his own experiences and ideas. The interview was conducted in Korean, and the overall message and tone was delivered to and reconstructed by the author. After the completion of the paper, Professor Choe gave his consent to have the paper translated into English.

\section{Foreword: About Choe Seung-Urn}

Choe Seung-Urn is a Professor of Earth Science Education at Seoul National University in Korea and has made significant contributions to research in the field of science education in Korea over the past 35 years. Before starting the interview, a brief overview of Professor Choe's career is as follows (see Table 1). Table 1 shows the positions he has held in gifted science education during his career.

Professor Choe received his BS and MS degrees in astronomy from Seoul National University. He received his doctoral degree in astrophysics from the University of Minnesota in the United States (1984). Since 1985 he has been a professor in the Department of Earth Science Education at Seoul National University (SNU). He will retire from his professorship in August 2019. Professor Choe has performed numerous roles in science education for 35 years.

In addition, Professor Choe has contributed to the development of science education in Korea via outstanding research achievements. He published 106 papers from 1994 to 2019 in the fields of astronomy, earth science, and science education. Through creative and innovative research, he has pioneered a truly interdisciplinary field that covers natural science and science pedagogy. Some of his representative papers on gifted science

\footnotetext{
${ }^{1}$ These searches were conducted on September 30th, 2019.

${ }^{2}$ In Korean language and customs, the family name (Choe) is always used before the given name (Seung-urn). In this paper, I use this system for introducing and discussing the research of different Korean scholars.
} 
Table 1 Choe Seung-Urn's positions in gifted science education

\begin{tabular}{|c|c|c|}
\hline Year & Title & Institute/Society \\
\hline $2001-2006$ & Director & SNU Gifted Science Education Center \\
\hline 2004-2006 & Chairman & $\begin{array}{l}\text { The Council of the National Association of Science Gifted Education Centers in the } \\
\text { Universities in Korea } \\
\text { (전국 대학교 과학영재교육원장 협의회) }\end{array}$ \\
\hline $2003-2006$ & Vice president & International Astronomy Olympiad \\
\hline 2004-2006 & Vice president & The Korean Society for the Gifted (한국영재학회) \\
\hline $2008-2012$ & Vice president & International Earth Science Olympiad \\
\hline 2012-2013 & Editor-in-chief & $\begin{array}{l}\text { The Journal of Gifted and Talented Education } \\
\text { (영재교육학회지) }\end{array}$ \\
\hline $2008-2016$ & Head director & Gwanak-gu Gifted Education Center \\
\hline 2018-2019 & Head director & $\begin{array}{l}\text { SNU BK Plus Project Team } \\
\text { ("Together" Science Education for the Future Project Team) }\end{array}$ \\
\hline
\end{tabular}

education are "Considering Criteria in Making Test Questions in Scientific Creative Problem Solving for Science Gifted Education” (Choe \& Chun, 2004), "Development and Implementation of 'Inventories for Evaluating Science Gifted Education Programs' in the SNU Gifted Science Education Program (서울대학교 과학영재 프로그램의 학 습 목표, 과학적 모형, 과학탐구의 인지과정 분석)" (Chun \& Choe, 2005), "Perception of the Scientifically Gifted and Long-Term Effects of a Science Gifted Education Program From the Students' Perspectives" (Chun, Shin, Lee, \& Choe, 2008), and "A Study of Gifted Students' Perceptions of a Gifted Education Program Based on the Autonomous Learner Model (자율학습자 모형에 기반한 영재교육 프로그램에 대한 과 학영재 학생들의 인식 연구)" (Choe, Kim, Chun, \& Yu, 2012).

One of the most common criticisms of science education scholars is that there is a gap between genuine school environments and academic research. However, Professor Choe has been trying to disseminate complex astronomy and earth science concepts to the public in formats that are easier to understand. He has published a number of books on practical teaching methods that can be used in school settings and textbooks covering astronomy and earth science. Professor Choe has also translated and introduced foreign books into Korea. He published 51 books from 1994 to 2019. His representative books on gifted science education include Astronomy Electronic Textbook for the Gifted Science School (과학영재학교 천문학 전자교재) (Choe \& Jung, 2003), Understanding of Science with Mathematics and Computers (수학과 컴퓨터를 이용한 과학이해하기) (Choe \& Woo, 2009), Understanding of Astrophysics Using Excel (엑 셀 을 이용한 천체물리학의 이해) (Choe, 2012), and Astronomical Activity Using Modeling Learning: Orbital Motion of the Solar System (모델링 학습과 함께하는 천문 활동: 태양계 천체의 궤도 운동) (Choe, Yang, Park, \& Ga, 2018).

Professor Choe has also put unwavering effort into teaching science to young gifted students (see Fig. 1) and training his students while working as a professor. He has advised 17 Ph.D. students and 90 master's degree students to date, and most of his students remain active in various fields of science education. Professor Choe has received numerous awards in recognition of his achievements from diverse academic societies. Recently, he received a Letter of Appreciation from the Korean Society for the Gifted (한국영재학회), a Promotion Award from the Korean Association for Science Education (한국과학교육학회), an Academic Award and Achievement Award from the 


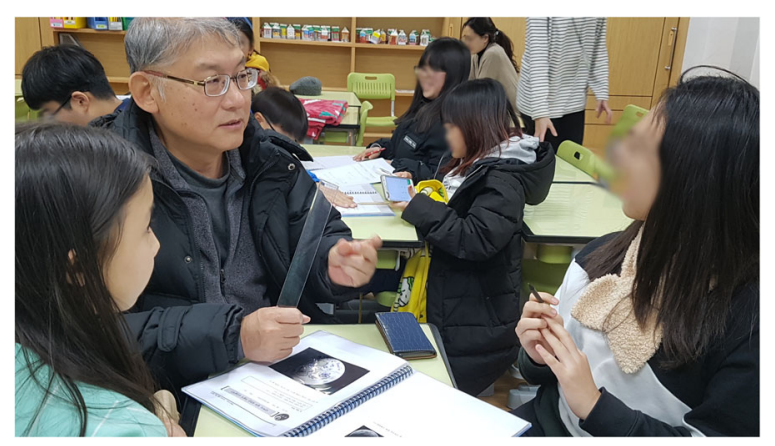

Fig. 1 Professor Choe teaching students at the Gwanak-gu Gifted Education Center

Korean Earth Science Society (한국지구과학회), and an Achievement Award from the Korean Astronomical Society (한국천문학회).

\section{The conversation}

\section{Encounter with science education}

Kang Da Yeon: Choe Seung-Urn, you studied astrophysics rather than science education in all of your undergraduate, graduate, and doctoral degree programs. What was the reason you first became interested in science education?

Choe Seung-Urn: I started my new post at the department of earth science education at SNU in 1985. At first, I tried to study astrophysics with students, but I found that the college of education aimed at education itself. I was a bit disconcerted, but it gave me a sense of purpose for education. Many students in the department wanted to conduct research in science education and to work in related professions. So I started to think about science education. Since then, I have been interested in what happens in elementary, middle, and high schools, so I started expanding my horizons for research.

Da Yeon: From 1985 to 2000, you were actively doing research in the field of astronomy. Starting in 2000, however, your focus moved from this type of research toward science education. Could you talk about this?

Seung-Urn: One of the main causes was the issue of professors transferring out of the college of education at SNU. At the time, many of the professors who were working at the college of education had majored in content studies. Around 2000, professors who had majored in natural science studies content were at a major crossroads, needing to decide whether to transfer to a college of natural science or to stay in the college of education. After much consideration, I concluded that training students who are engaged in education as professors at colleges of education would be the right and proper way. I thought that, even if I was working in astronomy, researching astronomy education was the right direction in which to go. I thought that insisting on astronomy just for personal satisfaction would set my career on a path that would sacrifice students. With 15 years of experience at the college of 
education, I thought it would be appropriate for me, my students, the department of earth science education, and the college of education to shift my research direction to education.

At that time, I was also thinking deeply about the future of my students. Some of the students I was teaching at that time were students doing research in astronomy, but other students were doing research in science education. I had been thinking about what course the students would choose once they got their degrees: Students who studied astronomy could go on to professorships or become researchers, while the career path for science education research majors was uncertain. Thus, I came to the conclusion that I needed to guide my students' doctoral dissertations properly so that students in science education research could choose a proper career path. So I moved away from astronomy research and went to the University of Iowa for a research year in science education research. I took the students who were doing research in science education with me so that they could study in the United States. Among these students were LI Hyun Sook of Konkuk University, SHIN MyeongKyeong, and $\mathrm{OH}$ Phil Seok of the Gyeongin University of Education.

Da Yeon: Were they your first students in the field of science education?

Seung-Urn: More specifically, they were the ones for whom I could provide guidance as an advising professor. Before that year, when students' enthusiasm was directed more toward science education, I could only provide a small amount of help. From that time, however, I think I started to provide the path with higher expertise. As I spent the research year at Iowa University, I was able to participate in the annual international conference of the National Association for Research in Science Teaching (NARST) and gain new ideas. One of my students, LEE Eun-Ah, was able to develop a Ph.D. thesis in science education, specifically about how to assess students' understanding of the nature of science (Choe \& Lee, 2003; Lee, 2001).

\section{Establishing the ground work for gifted science education}

Da Yeon: The year 2000, when you began to focus on science education research in earnest, was a very important year for gifted education in Korea, right? It was the year that the Promotion of Education for the Gifted and Talented Law was enacted.

Seung-Urn: In fact, the birth of gifted science education in our country dates back even further. JEONG Yeon-Tae in the department of physics education at SNU is likely the originator of gifted education. Professor Jeong had already retired in 1985 when I started my position at SNU, so he started gifted education at an off-campus private educational institution. Despite the fact that gifted education was not well known to the public at the time, he put in a significant amount of effort.

It was in the late 1990 s that gifted science education became a part of the system. In 1998, the SNU Gifted Science Education Center opened and gifted 
science education was started in earnest. At that time, it was the result of efforts made by WOO Kyu-Hwan in the department of chemistry education, CHANG Nam Kee in the biology education department, and myself, who felt the necessity of gifted education. In my case, I was mainly researching astronomy at the time. I wanted to provide a program where gifted students could study astronomy, so I got together with professors of science education who were interested in gifted education and submitted the proposal to the National Research Foundation, which was funded. Professor Woo was the first head director, followed by Professor Chang, and I became head director in 2001. After I became the head director, I restructured the organization and invited researchers to put gifted science education on track.

Da Yeon: The role of the SNU Gifted Science Education Center must have been very significant. How were gifted students in science identified at the time? I know the identification problem is very complex in the issue of gifted education. The debate continues as to how to identify which student is gifted and how to distinguish giftedness.

Seung-Urn: At that time, a great deal of consideration was given to this issue. Because experience in identifying gifted students was lacking, we depended on the Korean Educational Development Institute. The Korean Educational Development Institute identified students based on a standard they developed themselves and provided the list of students and their scores to universities. Thus, our center could not determine how the scores were given and on which standard they were based, making it extremely difficult to identify whether a given student was gifted. Not only that, we were unable to know who was responsible for doing the scoring based on which standard. Because the standard was unclear, numerous professors at the SNU Science Education Center continued to agonize over the issue.

In 2001, when I became the head director of the SNU Gifted Science Education Center, I invited researchers to conduct research on gifted science education. HAN Ki-Soon and CHUN Miran were researchers who worked hard to establish gifted science education at that time. Since no one was specialized in gifted education among the professors at the Gifted Science Education Center, it was not possible to provide a proper solution to the issue of identification. Considering various characteristics of giftedness, researchers at SNU Gifted Science Education Center developed a creative problem-solving ability test (Choe \& Chun, 2004; Jung, Han, Kim, \& Choe, 2002). Among the tools being used to determine giftedness, the creative problem-solving ability test provided very reliable validity in distinguishing giftedness in science. From that time, the creative problem-solving ability test, which could distinguish gifted students efficiently and objectively, was introduced. The test was conducted by presenting an appropriate science-related problem that students could solve creatively, and in-depth interviews were conducted to select autonomously. As the effectiveness of this method became known, it spread across the nation to other gifted education centers. 
Da Yeon: I am familiar with the testing method, as I also received gifted education in 2003 and 2004. I went to a gifted education center in the city where I lived, and I remember taking a test in the format you've described. In my case, the first selection was made based on the creative problem-solving ability test at each school, then the local provincial office of education made the second selection. In the second selection process, students were asked to give an answer to the creative problem-solving ability test question and explain the solution in front of the evaluation committee members. At the time, it felt quite difficult, as the evaluation committee asked very critical questions. It is very interesting that the selection I experienced was based on the research of the SNU Gifted Science Education Center.

Seung-Urn: Ha-ha, that could be described as a historical event. There is another thing that I contributed to the gifted selection process. I introduced a teacher's observation and recommendation in the selection process of the Gwanak-gu ${ }^{3}$ Gifted Science Education Center. I was the Director of the Regional Gifted Education Center in Gwanak-gu from 2008 to 2016. Unlike the SNU Gifted Science Education Center, because the Gwanak-gu Gifted Education Center was operated with support from the Gwanak-gu Local Government, it could be operated more freely and could make more diverse trials. During that time, the educational achievement level of Gwanak-gu was relatively lower than in other regions due to its low socio-economic situation, so it was difficult to distinguish the giftedness of students. The students solved problems, but it wasn't clear whether they had the basic knowledge. As they were in a difficult socio-economic situation, they might not have had enough opportunities to manifest their creativity. Trying to select students while considering all these factors resulted in the cost and time becoming insurmountable. This type of identification method was needed, but it was difficult to implement in reality. Therefore, I tried to identify giftedness in the first phase based on teachers' observations (Gwanak-gu Gifted Education Center holds a teacher workshop about teacher observation, 2009). Because teachers were able to observe students closely and continuously, they could effectively determine the potential of students. The students the teachers recommended based on their observations would then go to the gifted education centers to be selected based on in-depth interviews. This method was effective in finding students whose giftedness was not revealed by testing and was also effective in reducing the increasing need for private education to prepare for the creative problem-solving ability test. This method then spread to all gifted education centers nationwide.

\section{Communication with gifted education institution and the public}

Da Yeon: It is very interesting that what you did influenced gifted education in all of Korea. Because the types of gifted education in Korea are so diverse, ${ }^{4}$ communication about the purpose and direction of gifted education is critical. I

\footnotetext{
${ }^{3}$ Gwanak-gu is one of 25 districts in the city of Seoul and is the district where SNU is located. ${ }^{4}$ Gifted education in Korea is carried out at various levels including provincial offices of education, local governments, universities, and individual schools.
} 
think sharing of good educational methods and practices among gifted education institutions is required.

Seung-Urn: You're right. While I was the chairman of the Council of the National Association of Science Gifted Education Centers in the Universities in Korea from 2004 to 2006, there were two things that I was particularly concerned about. First was combining the actual educational scene and research on gifted science education. At that time, gifted science education was led by universities. The method was that gifted junior high and high school students would visit universities to receive gifted education. I considered it important, though that the method for gifted science education that we used should benefit everyone, including university students, graduate students, and gifted students. Because universities are in fact a place for educating undergraduate students and where graduate students conduct their research, I thought that gifted education centers at universities should be operated both as labs where field study and research are conducted for gifted education and as places for teaching gifted students. In fact, while I was the head director of the Gwanak-gu Gifted Education Center, research work on gifted science education was actively conducted. About 50 papers were published related to gifted science education from 2008 to 2016, and five students received their Ph.D. degrees. If a gifted education institution is part of a university, I think the institution must achieve both directions-research and education. Of course, in order to do so, there must be economic support for the gifted education field study in addition to the education of the gifted students.

Second, I tried to expand the exchange between gifted education centers. Although the directors of gifted science education centers at universities nationwide had knowledge in their majors, they were somewhat lacking in specialized knowledge about gifted education. Therefore, I did a lot of work toward increasing communication among gifted science education centers at universities around the country while developing good programs. Because each university had its own characteristics and strengths, I thought that it would be good for them to operate their own specialized programs while developing common programs together (Council of National Association of Science Gifted Education Centers in the Universities of Korea, 2005). At that time, based on the cooperation between the governmental agency and provincial offices of education, diverse programs and textbooks were developed. In addition to proceeding with cooperation between gifted science education centers at domestic universities, I tried to communicate with gifted science education institutions overseas.

Da Yeon: It seems that new and diverse teaching and learning methods can be tried in the context of gifted education. Having said that, I think it is important to communicate what kind of practices are being conducted at the forefront of science education while expanding the objects of such communication. Regrettably, however, I think that the educational materials and methods used in the field of gifted science education are not effectively shared with the public. Of course, because there are diverse gifted education institutions, the exchange among institutions is also lacking. 
Seung-Urn: One of the meaningful things that I did while I was the head director of the SNU Gifted Science Education Center was that I tried to deliver the results of gifted education to the public. Since 2001, the activities and relevant research being conducted at the SNU Gifted Science Education Center have been published in a journal format (see Fig. 2) in order to disseminate information on class methods at the Center and the results of these classes. The name of the journal is Gi Bbeo Yo, which is a shortened transliteration into Korean of Gi (fted education) Fo(r) You (the Korean title is 기뻐요, which means "I'm happy"). In the first year of its publication, it summarized what type of classes were offered to students by professors and researchers and what effects they achieved. It was one very thin volume. However, as the years went by, the parts that students were responsible for grew, and the education of the gifted education center gained momentum, causing the volume to become thicker. At that time, the popularity of gifted education was truly significant. However, because there were no teachers who could demonstrate gifted science education and no teaching materials that could be used for gifted science education, I think that publishing references that people who were interested in gifted education could use was very meaningful work. While all this was occurring, in 2006 I ended my term as the head director of the SNU Gifted Science Education Center when I went to do a research year at the Iowa University, after which the publication of the journal also stopped. In many ways, it is regrettable.

\section{Gifted science education as "how"}

Da Yeon: You have contributed significantly to establishing the framework for gifted science education in Korea. Over the last 20 years, I believe that many things must

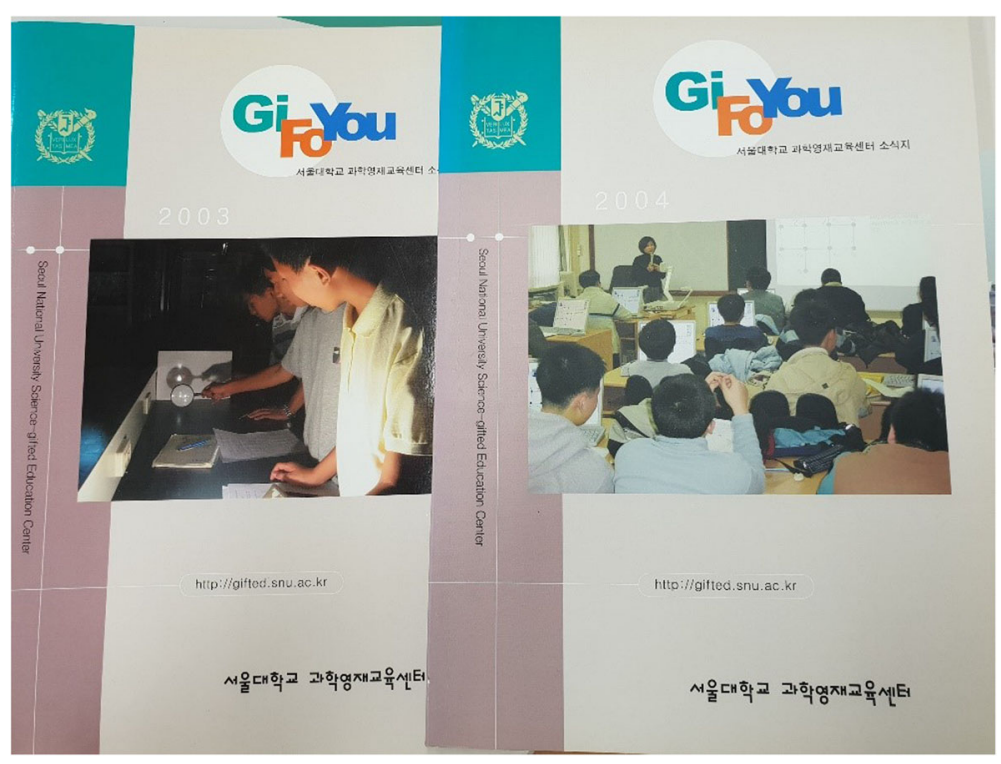

Fig. 2 The journal 'Gi Bbeo Yo' published by the SNU Gifted Science Education Center 
have happened during the time of your work in the field of gifted education. Can you share some notable occasions?

Seung-Urn: You're right. I can share a few of the many things that happened. First, I went on a field trip to the Korean Minjok Leadership Academy ${ }^{5}$ with my earth science class students from the SNU Gifted Science Education Center in 1998. One of the earth science teachers at the school asked our students, "Do you know how many stars are in our galaxy?" My students could not answer because they never learned it. Then the teacher said, "How do students who receive gifted science education not know this?" Suddenly a student raised his hand and asked, "How do you know it?" What my students had learned was that it was not whether they knew a certain piece of knowledge but whether they could learn it by some series of methods. Because they were educated as such, my students were more interested in how the teacher knew that there were hundreds of millions of stars in the galaxy than the fact that there were hundreds of millions of stars. At that time, I was proud to be a teacher because I thought that my students had potential to learn and had the right attitude.

The second anecdote happened when I was studying with students. In middle and high schools, students are taught that the orbit of the Earth is elliptical. But proving this at the student level is not easy. So when I said to the students, "If you went toward the back when you took a picture in kindergarten, please raise your hand," one student raised his hand. When I asked him why he went to the back, he said, "Because I have a big face." Kindergarten students also knew that if their faces were big, if they went toward the back, they would look smaller as they moved away. So I started a discussion with the students on the basis of a concept that even kindergartners know:

When we observe the sun from the earth, the sun is located closer if it is observed to be larger and farther away if it is observed to be smaller. The earth revolves around the sun at about one degree per day, you can see the orbit of the earth by drawing and connecting the sun every day.

So, when we actually drew the picture to measure the eccentricity, the result was similar to that calculated by experts. By using the concept that even kindergartners knew-the size looks different according to the distance from the observing point-we could personally prove a fact that we knew. It was this that I thought was important. Personally discovering how we can prove facts-for example, that the distance between the earth and the sun is 150 million $\mathrm{km}$ or that the luminous intensity of the sun is $4 \times 10^{23} \mathrm{~W}$-that we already know and where that proof came from is important.

${ }^{5}$ The Korean Minjok Leadership Academy is a first-generation gifted education school established in 1995 and is a well-known gifted education school in Korea. 
Da Yeon: You mean like authentic inquiry. There's a Korean proverb: "You must teach how to catch fish rather than give a fish that is already caught." I think it is important to teach students how to analyze a problem and which knowledge to utilize to solve the problem rather than forcing them to memorize by showering them with knowledge.

Seung-Urn: You're right. So I think that the focus of gifted science education should be in-depth rather than accelerated learning. Korean students often focus on acceleration in order to advance to a higher school. These students finish the high school mathematics and science curriculum in advance while they're still in their last year of middle school. I thought about this a lot while teaching gifted science students: At a gifted education institution, acceleration is not necessary. Acceleration is possible using numerous good textbooks available on the market. However, gifted education institutions must provide education that fosters higher-level thinking ability. I truly feel that it is important to have advanced programs where students can discover higher concepts using the knowledge and skills they developed in middle and high school. That is why I put a lot of effort into developing such a program. I asked for financial support from the government and hired researchers to develop an advanced program. However, due to various financial and administrative problems, this aim was not fully achieved.

Da Yeon: I think that the programs you've developed, however, are in fact successfully used by students. You developed a method of modeling astronomical phenomena using Excel and published many books on it. Recently I met a friend who is a teacher and heard that she was teaching the earth science inquiry class, and one of her students was calculating an astronomical phenomenon using Excel. So she asked the student, "Where did you learn it?" and the student said that he learned it from Professor Choe Seung-Urn. He attended the Gwanak-gu Gifted Education Center several years ago and learned how to easily calculate using Excel from you. After several years, when the student became a high school student, he was still using this method to solve problems.

Seung-Urn: It is good to hear. I said that I like solving higher-level problems using knowledge and methods that one can encounter in middle and high school. Excel is a cheap, basic program that is installed on most computers. Calculation is fast and the program can be used easily without learning a new computer language, which is very convenient. Using an Excel spreadsheet allows you to simply calculate complex differential equations and simultaneous equations associated with astronomy. Using graphs, animations, and so on, you can personally experience the process of calculation, which helps one to remember how you solve the problem. Using the Excel program is also easy to apply to various problems.

\section{Challenges faced by gifted science education}

Da Yeon: Those are the meaningful and fulfilling moments as an educator. Even when there are difficulties, you can forget about them when you see your students 
looking happy after learning new things. That is a kind of driving force for a life as an educator.

Seung-Urn: That is right. I've had many precious moments over the course of 20 years. While doing so, I fell in love with gifted science education.

Da Yeon: It's difficult to imagine the amount of affection you've accumulated over 20 years. In fact, recently, I was searching for articles about gifted science education and found one for which you were interviewed (Kim, 2015). It was about the closure of the Gwanak-gu Gifted Education Center in 2016. You mentioned that the Gifted Education Center became a means to go to a good high school outside of Gwanak$\mathrm{gu}^{6}{ }^{6}$ I could feel that you were genuinely concerned about the future of gifted education. Do you remember?

Seung-Urn: Oh, you read that article. Right. It's a pity. As many students who studied at the Gifted Education Center went to other special-purpose high schools (foreign language high schools, international high schools, science high schools, etc.) in other regions, Gwanak-gu stopped their support. The Center was established with the aim of providing a good educational environment for students in the area, so it's an understandable decision.

Da Yeon: Right. Gwanak-gu had to consider reality since the center was supported with local taxes. But I think we cannot blame individuals for leaving to go to a better educational environment.

Seung-Urn: That is right. I think this is a problem of social perception about gifted education. Most people think of gifted education as a way to go to a higher education school. Parents and even students are not considering what kind of education they will receive from gifted education institutions, but are rather thinking about which colleges they can go to if they get gifted education. The Science Olympiad is also thought of in this way. I was a vice president of the International Astronomy Olympiad from 2003 to 2006, and vice president of the International Earth Science Olympiad from 2008 to 2012. At first, I was enthusiastic about educating students, but I gradually became skeptical. The results were good as many students received prizes at the International Astronomical Olympiad, but they did not actually choose astronomy as a major afterwards. Most of the students who won the Astronomical Olympiad left to go to medical schools or selected other majors. Gifted science education eventually became a means for doing well on the college entrance examination (Im, Sung, Kim, \& Choe, 2011). Even if science gifted education is faithful to its original purpose, the government's policies and social perceptions limit fostering the development of science gifted students. In recent years, having received gifted

${ }^{6}$ Of the 91 students who graduated from the Gwanak-gu Gifted Education Center in 2015, only 35 students (38.5\%) entered high schools located within Gwanak-gu. The other 66 students (61.5\%) entered schools including specialized schools outside of Gwanak-gu. 
education has become less helpful for doing well on the college entrance exam. As such, enthusiasm toward gifted education has also waned.

\section{Moving forward}

Da Yeon: As I talk with you today, I think we could reflect a lot on the past and present of gifted science education in Korea. The next step then will be about the future. What do you think gifted science education should aim for in the future?

Seung-Urn: In fact, there is no special definition of gifted science education. When we identify a gifted science student, we consider the potential creativity innate in the student. Creativity is something that can appear when a student thinks through a problem for a long time and when the relevant information is accumulated. It cannot be seen by letting the student solve a problem in a short period of time or do a certain activity. Accordingly, whether we can evaluate the potential creativity of a student is not clear. Also, creativity appearing in a student, doesn't necessarily mean that it will help to solve problems. Even when a student suggests a creative answer, they may fail to solve the problem. Of course, this failure can be the key to the solution. However, solving a problem does not translate into being accepted by the science community. I think that gifted science education institutions need to be places where students can experience this whole process. Experiencing such a process means that students learn a type of methodology they can use in their future lives. Gifted science education institutions need to provide education that combines diverse academic fields such as technology and engineering within the context of science.

Da Yeon: I see. You are retiring this semester after a 35-year professorship. Can you give any advice to junior researchers from the perspective of someone who walked through the history of gifted science education?

Seung-Urn: Regardless of discipline, when you do research your vision can become very narrow. As the research deepens, it will deal with very specific areas that need expertise. As a pedagogical researcher, for example, some researchers will examine flipped learning, while others will research co teaching practices. All these studies have their own meaning. However, I hope junior researchers will consider the whole picture of education. Researchers will conduct studies about specific topics they are interested in, but what students actually experience is an integrated form of all these areas. Because education is a complex system, various phenomena occur together and interact with each other. What we should aim for in education research, I think, should be holistic education ("온-교육," "on-gyoyuk" in Korean, with "on" meaning "whole" or "all" and "gyoyuk" meaning "education") where all research fields are combined together. Although you may gain expertise for each research field, you must be able to draw a blueprint of the entirety of education to become a true educational researcher. 
Da Yeon: Thank you for those insightful words. What are you planning to do after your retirement?

Seung-Urn: After my retirement, I am preparing to write articles introducing ancient astronomy. In recent years, I have been reading Ptolemy's Almagest, a compilation of ancient astronomy, thinking of ways to make it easier to communicate the content educationally. Of course, many are studying this, but I think I can put my own spin on it by including educational implications. I am thinking of what I can do as a person who majored in astronomy as well as science education.

Da Yeon: That sounds very exciting. I look forward to your future steps. Thank you.

\section{Concluding thoughts}

As it was described in our conversation, Professor Choe Seung-Urn contributed to both the fields of astrophysics and science education by balancing his research interests to include a focus on both content-and-education. He also helped to produce many experts in science education, including present-day researchers and teacher practitioners. Especially in gifted science education, he and his colleagues founded and introduced a model for implementing gifted education via university partnerships, which has led to a proliferation of gifted education centers administered by universities in Korea. Considering the potential of students' giftedness, his efforts have contributed to the development of several methods that are used to identify students' creative problem-solving abilities and that are employed by teachers in classroom settings in which gifted students can be identified through more holistic methods, including teachers' diagnostic observations of students as learners.

In addition to building the initial structures guiding the development of gifted science education in Korea, Professor Choe has worked to involve diverse stakeholders, such as junior researchers and directors of nationwide gifted education institutions, in the ground-up development of gifted education initiatives. He also sought to develop general education programs in gifted education centers at universities to provide the general public with access to specialized education resources. Professor Choe has emphasized on the importance of the in-depth, long-term approaches to the development of students' talents and abilities rather than focusing simply on the accelerative learning approach more commonly used when teaching gifted students. He insists that gifted science education institutions should aim to foster students who can generate solutions based on knowledge and skills that they already possess, which can develop their creative thinking. Simultaneously, he has cautioned against practices that lead the public to misinterpret the goal of engaging in gifted education as simply a means for entering high-ranked colleges.

Reflecting on this conversation with Professor Choe, who has devoted his whole academic career to developing gifted science education in Korea, can give readers deep and impressive insights about giftedness. At the end of our interview, Professor Choe did not provide any clear definition of what is gifted science education, which is an important point to make. Historically, there have been continuous efforts to define the 
concept of giftedness (Gardner, 1983; Renzulli, 2005; Spearman, 1904; Tannenbaum, 1986). The essential aspects and characteristics of giftedness that researchers have explored are diverse, but there continues to be no one true definition of what it means to be gifted.

As time goes by, and as the values and interests that researchers pursue change, the direction and the aim of gifted science education have also changed. For junior researchers interested in conducting gifted science education studies, Professor Choe advises them to consider the complex and holistic features of education (ongyoyuk). Adding their own ontological, epistemological and axiological stance and interpretations to existing literature, junior researchers can determine a vision for the future direction of gifted education. This is how gifted science education as a field can flourish, much like the Korean proverb: "You must know the past to know the present and the future."

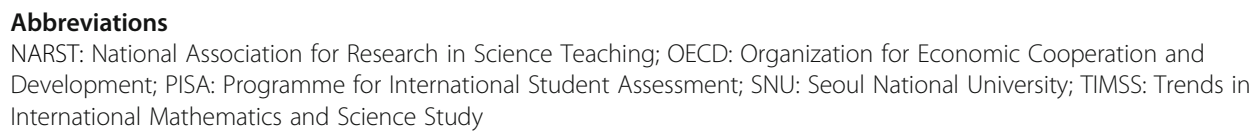

\section{Acknowledgements}

This research was supported by BrainKorea 21 PLUS project through the National Research Foundation of Korea (NRF) funded by the Ministry of Education (21B20151713505).

\section{Authors' contributions}

Both the author and the interviewee read and approved the final manuscript.

\section{Authors' information}

Da Yeon Kang is a doctoral candidate in Science Education in the Earth Science Education department at Seoul National University. Her research focuses on expanding science teaching and learning opportunities in diverse contexts. She is particularly interested in improving teacher education programs, which expand teachers' exposure to and awareness about diverse learners in Korean K-12 science classrooms. She is also interested in engaging students in science activities to change their own lives and communities regarding environmental issues.

\section{Funding}

This research was supported by BrainKorea 21 PLUS project through the National Research Foundation of Korea (NRF) funded by the Ministry of Education (21B20151713505).

\section{Availability of data and materials}

All data discussed is available from sources cited in the paper. The data sets can be made available from the corresponding author on reasonable request.

\section{Ethics approval and consent to participate}

The data collected from this project was obtained with the informed consent of the scholar being interviewed for this study.

\section{Consent for publication}

The authors agree that this article will be published in the APSE journal.

\section{Competing interests}

The authors declare that they have no competing interests to report.

Received: 11 August 2019 Accepted: 13 November 2019

Published online: 04 December 2019

\section{References}

Bak, S. (2017, July 24). South Korean teens swept math, physics Olympiads. The Korea herald. Retrieved from http://www. koreaherald.com/view.php?ud=20170724000626

Choe, S. U. (2012). Understanding of astrophysics using excel (엑셀을 이용한 천체물리학의 이해). Seoul: Bookshill.

Choe, S. U., \& Chun, M. R. (2004). Considering criteria to make test questions of scientific creative problem solving for science gifted education. The SNU Journal of Education Research, 13, 27-48.

Choe, S. U., \& Jung, H. C. (2003). Astronomy electronic textbook for the gifted science school (과학영재학교 천문학 전자교재) Korea Gifted and Talented School of Science. 
Choe, S. U., Kim, E. S., Chun, M., \& Yu, H. W. (2012). A study about the perception of scientifically gifted students regarding a program for gifted, based on autonomous learner model (자율학습자 모형에 기반한 영재교육 프로그램에 대한 과 학영재 학생들의 인식 연구). Journal of Gifted/Talented Education, 22(3), 575-596.

Choe, S. U., \& Lee, E. A. (2003). Development of the test instrument to assess students' progress in understanding nature of science: Based on AAAS Benchmarks for Science Literacy. Journal of the Korean Earth Science Society, 24(2), 93-99.

Choe, S. U., \& Woo, H. G. (2009). Understanding of science with mathematics and computer (수학과 컴퓨터를 이용한 과학이 해하기). Seoul: Cheongbum Publishing Company.

Choe, S. U., Yang, S. G., Park, S., \& Ga, S. H. (2018). Astronomical activity with modeling learning: Orbital motion of the solar system (모델링 학습과 함께하는 천문 활동: 태양계 천체의 궤도 운동). Seoul: Education Science Publishing.

Chun, M. R., \& Choe, S. U. (2005). Development and implementation of "inventories of evaluating science gifted education program"-centering around SNU gifted science education program. The SNU Journal of Education Research, 14, 77-107.

Chun, M. R., Shin, Y. J., Lee, S. M., \& Choe, S. U. (2008). Perception of the scientifically gifted and long-term effects of science gifted education program - from the students' perspectives. Journal of the Korean Association for Science Education, 28(3), 241-252.

Council of National Association of Science Gifted Education Centers in the Universities of Korea. (2005). Policy study on the further development of the National Association of science gifted education centers in the universities. Daejeon: Korea Science and Engineering Foundation.

Gardner, H. (1983). Frames of mind: The theory of multiple intelligences. New York: Basic Books.

Gifted Education Database. (2019). Basic trends of gifted education Retrieved from https://ged.kedi.re.kr/stss/main.do.

Gwanak-gu Gifted Education Center holds a teacher workshop about teacher observation. (2009, April 6) The Asia Business Daily. Retrieved from http://www.asiae.co.kr/news/view.htm?idxno=2009040609443591642

Im, I. S., Sung, H., Kim, Y. J., \& Choe, S. U. (2011). A follow-up study on the participants of international astronomy Olympiad competitions (천문올림피아드 국제 대회 참가자에 대한 추적 연구). Publications of the Korean Astronomical Society, 26(3), 102-114.

Jung, H. C., Han, K. S., Kim, B. N., \& Choe, S. U. (2002). Development of programs to enhance the scientific creativity: Based on theory and examples (과학 창의성 계발을 위한 프로그램 개발: 이론과 예시를 중심으로). Journal of the Korean Earth Science Society, 23(4), 334-348.

Kim, M. (2015, March 24). Students enter schools outside: Gwanak-gu closes the gifted education center. Hankyoreh. Retrieved from http://www.hani.co.kr/arti/society/society_general/683662.html

Korean Ministry of Education. (2003). The primary plan of the promotion of education for the gifted and talented law. Seoul: Korean Ministry of Education http://gifted.kedi.re.kr/khome/gifted/gedEng/history.do.

Korean Ministry of Science and ICT (2017). Korean team ranks 5th at 28th international biology Olympiad (BBO) Retrieved from https://english.msit.go.kr/english/msipContents/contentsView.do?cateld=msse42\&artld=1360322.

Lee, E. A. (2001). Development of a pool for test items to assess student progress in an understanding of the nature of science: Based on AAAS Benchmarks for Science Literacy (Unpublished doctoral dissertation). Seoul National University, Seoul, Republic of Korea.

Lee, H. (2015, December 14). Korea places third at international junior science Olympiad. Korea.net. Retrieved from http:/ www.korea.net/NewsFocus/Sci-Tech/view?articleld=131333

Lee, S. H., \& Choi, S. I. (2015). Comprehensive review of research publications on gifted education in Korea: 2003-2012 (한국 영재교육 연구의 현황 및 성과: 2003-2012). Journal of Gifted/Talented Education, 25(6), 881-904.

Marica, I. (2014, July 24). Watching the skies: International astronomy Olympiad takes place in Romanian city this summer. Romania-insider.com. Retrieved from https://www.romania-insider.com/watching-the-skies-international-astronomyolympiad-takes-place-in-romanian-city-this-summer

Martin, M. O., Mullis, I. V. S., Foy, P., \& Hooper, M. (2016). TIMSS 2015 international results in science. TIMSS \& PIRLS International Study Center, Boston College, Boston, MA, USA.

Martin, M. O., Mullis, I. V. S., \& Foy, R. (in collaboration with Olson, J. E., Erberber, E., \& Galia, J.)(2008). TIMSS 2007 international science report: Findings from IEA's trends in international mathematics and science study at the fourth and eighth grades. Chestnut Hill: TIMSS \& PIRIL International Study Center.

Organization for Economic Cooperation and Development [OECD]. (2014). PISA 2012 results: What students know and can do (volume I, revised edition, February 2014): Student performance in mathematics, reading and science. Paris: OECD Publishing. https://doi.org/10.1787/9789264208780-en.

Organization for Economic Cooperation and Development [OECD]. (2016). PISA 2015 results in focus, PISA in focus, no. 67. Paris: OECD Publishing. https://doi.org/10.1787/aa9237e6-en.

Renzulli, J. S. (2005). The three ring conception of giftedness: A developmental model for promoting creative productivity. In R. J. Sternberg \& J. E. Davidson (Eds.), Conceptions of giftedness (2nd ed., pp. 246-280). New York: Cambridge University Press.

Spearman, C. (1904). "General intelligence", objectively determined and measured. American Journal of Psychology, 15(2), 201-293.

Tannenbaum, A. J. (1986). Giftedness: A psychosocial approach. In R. J. Sternberg \& J. E. Davidson (Eds.), Conceptions of giftedness (pp. 21-252). New York: Cambridge University Press.

Yi, S. (2017). Comparison of international mathematical Olympiad participation histories of Korea, China, and Japan (한국, 중 국, 일본의 국제수학올림피아드 참가 역사 비교). Journal for History of Mathematics, 30(2), 121-133.

\section{Publisher's Note}

Springer Nature remains neutral with regard to jurisdictional claims in published maps and institutional affiliations. 